\title{
Lessons Learned from the Exercise of Universal Jurisdiction in Respect of Gross Human Rights Violations.
}

\author{
Citation for published version (APA):
}

Kamminga, M. T. (2001). Lessons Learned from the Exercise of Universal Jurisdiction in Respect of Gross Human Rights Violations. Human Rights Quarterly, 23, 940-974. https://doi.org/10.1353/hrq.2001.0057

\section{Document status and date: \\ Published: 01/01/2001}

DOI:

10.1353/hrq.2001.0057

\section{Document Version:}

Publisher's PDF, also known as Version of record

\section{Document license:}

Taverne

\section{Please check the document version of this publication:}

- A submitted manuscript is the version of the article upon submission and before peer-review. There can be important differences between the submitted version and the official published version of record. People interested in the research are advised to contact the author for the final version of the publication, or visit the DOI to the publisher's website.

- The final author version and the galley proof are versions of the publication after peer review.

- The final published version features the final layout of the paper including the volume, issue and page numbers.

Link to publication

\footnotetext{
General rights rights.

- You may freely distribute the URL identifying the publication in the public portal. please follow below link for the End User Agreement:

www.umlib.nl/taverne-license

Take down policy

If you believe that this document breaches copyright please contact us at:

repository@maastrichtuniversity.nl

providing details and we will investigate your claim.
}

Copyright and moral rights for the publications made accessible in the public portal are retained by the authors and/or other copyright owners and it is a condition of accessing publications that users recognise and abide by the legal requirements associated with these

- Users may download and print one copy of any publication from the public portal for the purpose of private study or research.

- You may not further distribute the material or use it for any profit-making activity or commercial gain

If the publication is distributed under the terms of Article $25 \mathrm{fa}$ of the Dutch Copyright Act, indicated by the "Taverne" license above, 


\section{PROJECT MUSE}

Lessons Learned from the Exercise of Universal Jurisdiction in Respect of Gross Human Rights Offenses

Menno T. Kamminga

The

Johns

Hopkins

University

Press

Human Rights Quarterly, Volume 23, Number 4, November 2001, pp. 940-974

(Article)

Published by Johns Hopkins University Press

DOI: https://doi.org/10.1353/hrq.2001.0057

$\Rightarrow$ For additional information about this article https://muse.jhu.edu/article/13808 


\title{
Lessons Learned from the Exercise of Universal Jurisdiction in Respect of Gross Human Rights Offenses
}

\author{
Menno T. Kamminga*
}

\section{INTRODUCTION}

On 11 April 2000, Belgian investigating magistrate Damien Vandermeersch signed an arrest warrant against the Foreign Minister of the Democratic Republic of the Congo, Abdulaye Yerodia Ndombasi. The warrant alleged that in August 1998 Mr. Yerodia had committed grave violations of international humanitarian law by publicly referring to members of the Tutsi ethnic group as "vermin" and calling for their "extermination." On 17 October 2000, Congo responded by bringing proceedings against Belgium before the International Court of Justice in The Hague. In its application Congo asserted that the action taken by the Belgian magistrate represented interference in its internal affairs and that it was incompatible with the diplomatic immunity of its Foreign Minister. The application was accompanied by a request for the indication of a provisional measure. ${ }^{1}$

The attempt to bring the Congolese Foreign Minister before a Belgian court in connection with crimes allegedly committed against Congolese nationals in Congo is the most spectacular example yet of the increasing

\footnotetext{
* Menno T. Kamminga is Professor of International Law at Maastricht University and CoDirector of the Maastricht Centre for Human Rights. This is a revised and updated version of a report prepared by the author for the International Law Association's Committee on International Human Rights Law and Practice, Final Report on the Exercise of Universal Jurisdiction in Respect of Gross Human Rights Offences, in Report of the 69th Conference of the InTERnATIONAL LAW Association 403-31 (2000).

1. Application and Request for the Indication of a Provisional Measure by the Democratic Republic of the Congo against Belgium, 17 Oct. 2000. The indication of a provisional measure was refused by the Court on 8 December 2000 on the grounds that the matter was no longer urgent since the accused was no longer Foreign Minister. Texts available at $<$ http://www.icj-cij.org.html>.
} 
willingness of domestic judicial authorities to bring proceedings against gross human rights offenders on the basis of universal jurisdiction. Much has changed since the then Legal Adviser of the International Committee of the Red Cross wrote in 1986 that universal jurisdiction was of "no practical value" for war crime trials. ${ }^{2}$ During the past seven years, ten perpetrators of gross human rights offenses in the former Yugoslavia and Rwanda (including several perpetrators of genocide) were successfully brought to trial and convicted on the basis of universal jurisdiction in Belgium, Denmark, Germany, and Switzerland. Proceedings on the basis of universal jurisdiction not (yet) resulting in convictions were also brought in Austria, France, the Netherlands, Senegal, Spain, and the United Kingdom in respect of crimes committed in Chad, Chile, Mauritania, Rwanda, Sudan, and Yugoslavia. ${ }^{3}$ In other words, after decades in which the principle of universal jurisdiction for gross human rights offenses laid dormant in treaty provisions, it is beginning to move to center stage.

Circumstances which contributed to this development probably include widespread public concern about the atrocities committed in the former Yugoslavia and Rwanda; the increasing effectiveness of the International Criminal Tribunals for the former Yugoslavia (ICTY) and Rwanda (ICTR); and the establishment of the International Criminal Court (ICC). Partly in response to Security Council decisions under Chapter VII of the UN Charter and partly in response to the adoption of the Statute of the ICC a growing number of states have adopted implementing legislation specifically enabling them to bring persons to trial on the basis of universal jurisdiction. The successful example set by the ICTY and ICTR in bringing perpetrators to justice is likely to have inspired and given courage to domestic prosecutors.

Nevertheless, the exercise of universal jurisdiction in respect of gross human rights offenses raises a series of legal and practical problems that have hardly begun to be considered. The purpose of this article is to take stock of the case law so far, to identify the difficulties that have arisen, and to consider how they might be overcome.

\section{WHAT IS UNIVERSAL JURISDICTION?}

Under the principle of universal jurisdiction a state is entitled or even required to bring proceedings in respect of certain serious crimes, irrespective of the location of the crime, and irrespective of the nationality of the

2. Yves Sandoz, Penal Aspects of International Humanitarian Law, in International Criminal Law 209, 230 (M. Cherif Bassiouni ed., 1986).

3. For details, see app. 
perpetrator or the victim. ${ }^{4}$ This paper is concerned with jurisdiction to adjudicate, specifically the exercise of criminal jurisdiction by domestic courts in respect of gross human rights offenses. It does not cover enforcement jurisdiction or the exercise of jurisdiction for the purpose of obtaining civil law remedies. ${ }^{5}$ The term "gross human rights offences" is employed as shorthand for certain serious violations of international humanitarian law and international human rights law that qualify as crimes under international law.

It follows from this definition that, with one or two exceptions, the postSecond World War trials usually cited as examples of the exercise of universal jurisdiction in fact do not deserve this label. The military tribunals sitting in Germany, Italy, the Netherlands, and on Kwajalein Island that tried the "non-major" war criminals generally failed to indicate any explicit legal basis at all for their exercise of jurisdiction. However, they usually tried offenses committed against their own nationals. ${ }^{6}$ The assumption of jurisdiction in these cases was therefore based on the passive personality principle, especially if it is assumed that this principle also enables the exercise of jurisdiction with regard to crimes committed against nationals of a belligerent's ally. ${ }^{7}$

Universal jurisdiction was explicitly relied upon to bring Adolf Eichmann and John Demjanjuk to justice in Israel but this was merely one among several jurisdictional grounds. The Israeli Supreme Court that convicted Eichmann $^{8}$ and the US courts which decided to permit Demjanjuk's extradition to Israel ${ }^{9}$ relied not only on the universal jurisdiction principle but also on the protective principle and the passive personality principle. ${ }^{10}$ They thus agreed that there was a connection between the offenses of which

4. See Kenneth C. Randall, Universal Jurisdiction under International Law, 66 TEx. L. Rev. 785, 788 (1988).

5. In the United States universal jurisdiction has been exercised with some success for the purpose of obtaining civil law remedies under the Alien Tort Claims Act and the Torture Victim Protection Act. For an overview, see Beth Stephens, Expanding Remedies for Human Rights Abuses: Civil Litigation in Domestic Courts, 40 German Y.B. Int'L L. 117 (1997).

6. See the overview provided in Willard B. Cowles, Trials of War Criminals (NonNuremberg), 42 Aм. J. INT'L L. 299(1948).

7. See A.R. Carnegie, Jurisdiction over Violations of the Laws and Customs of War, 39 BRITISH Y.B. INT'L L. 402, 422-23 (1963).

8. Attorney-General v. Adolf Eichmann, Supreme Court of Israel, 29 May 1962, 36 ILR 5, 298-304; see J.E.S. Fawcett, The Eichmann Case, 38 BritISH Y.B. INT'L L. 181, 202-08 (1962).

9. See Rena Hozore Reiss, The Extradition of John Demjanjuk: War Crimes, Universality Jurisdiction, and the Political Offense Doctrine, 20 CorneLL INT'L L. J. 281, 302-07 (1987).

10. The term protective principle refers to the basis of jurisdiction when the crime affects the security of the country. 
the two men were accused and the state bringing them to justice, even though the State of Israel did not yet exist when the offenses were committed.

\section{RATIONALE FOR THE EXERCISE OF UNIVERSAL JURISDICTION}

The term "universal jurisdiction" appears to have been coined by Cowles in 1945. On the basis of a detailed analysis of state practice in response to "brigandism" (banditism), he concluded that every state had jurisdiction to punish war crimes regardless of the nationality of the victim, the time it entered into war or the place where the offense was committed. This was because war crimes, like piracy and brigandism, were to be regarded as offenses against the conscience of the civilized world and every nation therefore had an interest in their punishment. ${ }^{11}$

This justification is still valid. By qualifying certain crimes as being subject to universal jurisdiction the international community signals that they are so appalling that they represent a threat to the international legal order. Justice requires that there should be no safe haven for the perpetrators of such crimes. Domestic courts and prosecutors bringing the perpetrators to justice are not acting on behalf of their own domestic legal system but on behalf of the international legal order. The increasing exercise of universal jurisdiction in respect of gross human rights offenders is a reflection of the smaller world in which we live in which people feel affronted not merely by crimes committed within their own territories or against their own fellow citizens but also by heinous crimes perpetrated in distant states against others. They therefore regard it as appropriate that the machinery of justice in their state is used to bring the perpetrators to trial.

A different argument sometimes put forward, as a justification for the exercise of universal jurisdiction is its supposed deterrent effect. However, as always in the field of criminal justice, this effect should not be overstated. During the Second World War German atrocities continued to be committed unabated after the Allies had announced their intention to pursue the perpetrators "to the uttermost ends of the earth" and to deliver them to their accusers. ${ }^{12}$ More recently, serious crimes on a massive scale continued to be committed in Kosovo after the Chief Prosecutor of the ICTY had announced her intention of investigating and prosecuting these crimes in a letter addressed to President Milosevic and other senior Yugoslav officers. ${ }^{13}$

11. Willard B. Cowles, Universal Jurisdiction over War Crimes, 33 Cal. L. Rev. 177 (1945).

12. Declaration of German Atrocities, 1 Nov. 1943, 9 Dер'т Sт. Bull. 310, 311 (1943).

13. Letter from Justice Louise Arbour to President Milosevic and other senior officials, ICTY press release JL/PIU/389-E, 26 Mar. 1999. 
The key rationale for the exercise of universal jurisdiction, therefore, is not deterrence but justice. An interesting spin-off, moreover, may be its positive impact on the willingness of the territorial state to bring proceedings against gross human rights offenders. The authorities there may be shamed into action by the exercise of universal jurisdiction in another state, as is illustrated by the apparently positive impact of the detention of General Pinochet in the United Kingdom on proceedings against the General in Chile.

The scope of this paper is limited to the exercise of universal jurisdiction in respect of gross human rights offenses. It does not cover the exercise of universal jurisdiction with regard to various kinds of terrorist offenses. This is because the implementation of the principle of universal jurisdiction in these latter cases causes fewer difficulties. Unlike gross human rights offenders, pirates and aircraft hijackers present a material risk to citizens of all nations; states therefore need little encouragement to bring legal proceedings against them on the basis of universal jurisdiction.

\section{HUMAN RIGHTS OFFENSES SUBJECT TO UNIVERSAL JURISDICTION}

The work of the International Law Commission offers a convenient starting point for the identification of the crimes that are subject to universal jurisdiction under international law. In its 1996 Draft Code of Crimes against the Peace and Security of Mankind, the ILC suggested that genocide, crimes against humanity, crimes against United Nations and associated personnel, and war crimes are subject to universal jurisdiction. ${ }^{14}$ According to the Draft Code a state party in the territory of which an individual is found who is alleged to have committed one of these crimes shall extradite or prosecute that individual. ${ }^{15}$ The Draft Code does not define genocide, crimes against humanity, and war crimes. These concepts have recently been authoritatively defined, however, in Articles 6-8 respectively of the Statute of the ICC. Strictly speaking, the purpose of these latter provisions is merely to designate the crimes that are within the jurisdiction of the ICC. A reasonable assumption however, is that the offenses listed here will "take on a life of their own as an authoritative and largely customary statement of international humanitarian and criminal law, and may thus become a model

\footnotetext{
14. Draft Code of Crimes Against the Peace and Security of Mankind, arts. 8, 9, 17, 18, 19 \& 20, Report of the Int'l Law Comm'n on the Work of its Forty-Eighth Session, U.N. Doc. A/51/10, II 50.
}

15. Id. art. 9. 
for national laws to be enforced under the principle of universality of jurisdiction." 16 In addition to these crimes, torture not amounting to a crime against humanity is a crime subject to universal jurisdiction pursuant to the UN Convention against Torture. ${ }^{17}$ Following is a brief discussion of these four categories of offenses.

\section{A. Genocide}

Article 6 of the 1948 Genocide Convention provides that perpetrators of genocide must be tried by the territorial state or by an international criminal tribunal:

Persons charged with genocide or any of the other acts enumerated in article III shall be tried by a competent tribunal of the state in the territory of which the act was committed, or by such international penal tribunal as may have jurisdiction with respect to those Contracting Parties which shall have accepted its jurisdiction. ${ }^{18}$

The convention does not specifically provide for the exercise of universal jurisdiction by domestic courts. However, it is widely agreed that the offense of genocide is subject to universal jurisdiction as a principle of customary international law. ${ }^{19}$ State practice regarding the exercise of universal jurisdiction in respect of genocide supports this view. German courts have in recent years convicted two Bosnian Serbs of genocide committed against Muslims in Bosnia. ${ }^{20}$ Australian and Swiss courts have recently refused to exercise jurisdiction on the basis of the universality principle in respect of the crime of genocide but this was merely because the necessary enabling legislation was lacking. ${ }^{21}$

16. Theodor Meron, Crimes under the Jurisdiction of the International Criminal Court, in Reflections on the International Criminal Court 47, 48 (Herman A.M. von Hebel, Johan G. Lammers \& Jolien Schukking eds., 1999).

17. See generally Convention Against Torture and Other Cruel, Inhuman or Degrading Treatment or Punishment, adopted 10 Dec. 1984, G.A. Res. 39/46, U.N. GAOR, 39th Sess., Supp. No. 51, U.N. Doc. A/39/51 (1985) (entered into force 26 June 1987) reprinted in 23 I.L.M. 1027 (1984), substantive changes noted in 24 I.L.M. 535 (1985).

18. Convention on the Prevention and Punishment of the Crime of Genocide, adopted 9 Dec. 1948, 78 U.N.T.S. 277 (entered into force 12 Jan. 1951) (entered into force for the U.S. 23 Feb. 1989).

19. Restatement (Third) of the Foreign Relations Law of the United States (1987), II 404, Reporters' Note 1.

20. See app.

21. See id. 


\section{B. Crimes Against Humanity}

The concept of crimes against humanity has long lacked an authoritative definition. However, the Statute of the ICC has now filled this gap. Article 7 defines as crimes against humanity a number of practices, including murder, extermination, enslavement, deportation, imprisonment, torture, rape, persecution, enforced disappearance, and apartheid "when committed as part of a widespread or systematic attack directed against any civilian population, with knowledge of the attack." 22 No connection with an armed conflict is required.

The Statute understandably does not purport to enable domestic courts to exercise universal jurisdiction in respect of these crimes. However, it is widely considered that such exercise of jurisdiction is permitted under customary international law. ${ }^{23}$ An investigating magistrate in Brussels has recently ruled that alleged perpetrators of crimes against humanity committed abroad could be brought to justice in Belgium on the basis of customary international law. ${ }^{24}$ Belgium has subsequently amended its legislation to specifically enable its courts to exercise universal jurisdiction in respect of crimes against humanity. ${ }^{25}$

\section{War Crimes}

War crimes may be divided into two categories. The first category consists of grave breaches of the four Geneva Conventions of 1949, for example, offenses committed during international armed conflict. Offenses qualified as grave breaches in these instruments include willful killing, torture or inhumane treatment, and willfully causing great suffering. ${ }^{26}$ Parties to the

22. Rome Statute of the International Criminal Court, opened for signature 17 July 1998, art. 7, reprinted in 37 I.L.M. 999 (1998).

23. Nigel S. Rodley, The Treatment of Prisoners under International Law 125 (2d ed. 1999); M. Cherif Bassiouni, Crimes against Humanity in International Criminal Law 240 (2d ed. 1999).

24. Juge d'instruction à Bruxelles, ordonnance, 6 Nov. 1998, Revue de Droit Penal et de CRIMINOLOGIE 1999, 278, 288.

25. See app.

26. Geneva Convention (I) for the Amelioration of the Condition of the Wounded and Sick in Armed Forces in the Field, 12 Aug. 1949, 6 U.S.T. 3114, 75 U.N.T.S. 31, art. 50 (entered into force 21 Oct. 1950) (entered into force for U.S. 2 Feb. 1956); Geneva Convention (II) for the Amelioration of the Condition of Wounded, Sick and Shipwrecked Members of Armed Forces at Sea, 12 Aug. 1949, 6 U.S.T. 3217, 75 U.N.T.S. 85, art. 51 (entered into force 21 Oct. 1950) (entered into force for U.S. 2 Feb. 1956); Geneva Convention (III) Relative to the Treatment of Prisoners of War, 12 Aug. 1949, 6 U.S.T. 3316, 75 U.N.T.S. 135, art. 130 (entered into force 21 Oct. 1950) (entered into force for U.S. 2 Feb. 1956); Geneva Convention (IV) Relative to the Protection of Civilian Persons in Time of War, 12 Aug. 1949, 6 U.S.T. 3516, 75 U.N.T.S. 287, art. 147 (entered into force 21 Oct. 1950) (entered into force for U.S. 2 Feb. 1956). 
Geneva Conventions are required to enact legislation to enable them to try persons alleged to have committed such offenses, regardless of their nationality, to search for and prosecute such offenders and to assist each other in criminal proceedings in connection with these offenses. The exercise of universal jurisdiction is not permissive but clearly mandatory:

Each High Contracting Party shall be under the obligation to search for persons alleged to have committed, or to have ordered to be committed, such grave breaches, and shall bring such persons, regardless of their nationality, before its own courts. It may also, if it prefers, and in accordance with the provisions of its own legislation, hand such persons over for trial to another High Contracting Party concerned, provided such High Contracting Party has made out a prima facie case. ${ }^{27}$

The second category of war crimes consists of serious violations of Common Article 3 of the Geneva Conventions and other serious violations of the laws and customs applicable in armed conflicts not of an international character. These violations have traditionally not been considered as criminal offenses that are subject to universal jurisdiction. ${ }^{28}$ However, there is increasing support for the view that this position is no longer tenable. ${ }^{29}$ The atrocities committed during the armed conflicts in the former Yugoslavia and Rwanda have obviously contributed to this shift. The ICTR was specifically empowered by the Security Council to try perpetrators of serious violations of common Article 3 and Protocol II. ${ }^{30}$ While the ICTY was not granted this specific competence, in the Tadic case the Tribunal decided that customary international law imposes criminal liability for serious violations of common Article 3 and that it had jurisdiction with regard to such violations. ${ }^{31}$ The Statute of the ICC carefully identifies the serious violations applicable in internal armed conflicts with regard to which the Court has jurisdiction..$^{32}$ It is difficult to see why domestic courts would not have the competence to try these same offenses on the basis of universal jurisdiction. This conclusion finds support in a recent resolution

27. Geneva Conv. I, art. 49, Geneva Conv. II, art. 50, Geneva Conv. III, art. 129, Geneva Conv. IV, art. 146, supra note 26.

28. Denise Plattner, The Penal Repression of Violations of International Humanitarian Law Applicable in Non-international Armed Conflict, 30 Int'L Rev. Red Cross 409, 414 (1990).

29. See Thomas Graditzky, Individual Criminal Responsibility for Violations of International Humanitarian Law Committed in Non-International Armed Conflicts, 322 INT'L Rev. Red Cross 29-56 (1998); See also Theodor Meron, International Criminalization of Internal Atrocities, 89 AM J. INT'L L. 554 (1995).

30. ICTR Statute, art. 4, 33 I.L.M. 1598 (1994).

31. Prosecutor v. Dusko Tadic, Appeals Chamber of the ICTY, 2 Oct. 1995, II 137, 35 I.L.M. 32 (1996). See Christa Meindersma, Violations of Common Article 3 of the Geneva Conventions as Violations of the Laws or Customs of War under Article 3 of the Statute of the International Criminal Tribunal for the Former Yugoslavia, 42 NetherLANDS INT'L L. Rev. 375 (1995).

32. ICC Statute, supra note 22 , art. $8(2)(\mathrm{c}) \&(\mathrm{e})$. 
on the situation of human rights in Sierra Leone, adopted without a vote by the UN Commission on Human Rights. The resolution obviously assumes that the universal jurisdiction regime applies equally to crimes committed in international and internal armed conflict, even to the extent that states are not merely entitled but even required to search for perpetrators of grave breaches perpetrated in internal armed conflict. Remarkably, the resolution employs the term "grave breaches" for certain crimes perpetrated in both international and internal armed conflict. The Commission:

Reminds all factions and forces in Sierra Leone that in any armed conflict, including an armed conflict not of an international character, the taking of hostages, wilful killing and torture or inhuman treatment of persons taking no active part in the hostilities constitute grave breaches of international humanitarian law, and that all countries are under the obligation to search for persons alleged to have committed, or to have ordered to be committed, such grave breaches and to bring such persons, regardless of their nationality, before their own courts. ${ }^{33}$

A considerably longer list of war crimes (applicable without distinction in both international and non-international armed conflict) is contained in Article 8 of the Statute of the ICC. Strictly speaking the purpose of that provision is merely to designate the war crimes which are within the jurisdiction of the ICC. It is fair to assume, however, that this provision will also be regarded as an authoritative pronouncement on the violations of the law of war that qualify as war crimes under customary international law. ${ }^{34} \mathrm{~A}$ corollary then is that these offenses are covered by the principle of universal jurisdiction. ${ }^{35}$

\section{Torture}

Under the UN Convention against Torture, a state party is required to submit the case of an alleged torturer found in its territory to its competent authorities for the purpose of prosecution, if it does not extradite him:

The State Party in the territory under whose jurisdiction a person alleged to have committed any offence referred to in Article 4 is found, shall in the cases contemplated in Article 5, if it does not extradite him, submit the case to its competent authorities for the purpose of prosecution. ${ }^{36}$

\footnotetext{
33. UN Comm'n on Human Rights Resolution 1999/1, 6 Apr. 1999.

34. Meron, supra note 29.

35. See Yoram Dinstein, The Universality Principle and War Crimes, in The Law of Armed Conflict: Into the Next Millennium 17, 21 (M.N. Schmitt \& L.C. Green eds., 1998).

36. Convention Against Torture, supra note 17.
} 
The obligation is limited to persons found in a state's territory and therefore does not go as far as the Geneva Conventions, which contain a duty to search for persons, even when they are outside the territories of states' parties. A prosecutor must treat offenses in the same manner as if they had been committed in the prosecutor's own state. ${ }^{37}$ Since the prosecutor is acting on behalf of the international legal order, the fact that the crime may have been committed far away from the prosecutor's office has no bearing on his or her discretionary powers.

States not parties to the Convention against Torture are entitled, but not obliged, to exercise universal jurisdiction in respect of torture on the basis of customary international law..$^{38}$ The ICTY has pointed out that the entitlement of every state to investigate, prosecute, and punish or extradite individuals accused of torture, who are present in a territory under its jurisdiction is one of the consequences of the jus cogens character bestowed by the international community on the prohibition of torture ${ }^{39}$ Perpetrators of torture committed in states that are not parties to the Convention against Torture may therefore be brought to trial elsewhere on the basis of universal jurisdiction. Examples are the proceedings started recently in the United Kingdom and France against a Sudanese and a Mauritanian national for torture committed in Sudan and Mauritania, respectively. ${ }^{40}$ Sudan and Mauritania are not parties to the Convention against Torture.

\section{E. Other Crimes}

By its very nature, the principle of universal jurisdiction can apply only in a limited number of instances. ${ }^{41}$ For the time being, it may be wiser to concentrate on the need to exercise the principle with regard to the crimes to which it clearly applies under current international law rather than to focus on an expansion of the catalogue of crimes. Nevertheless, the number of offenses that are subject to universal jurisdiction in international law is likely to continue to increase. For example, perpetrating "forced disappearances" (on a scale not amounting to a crime against humanity) has recently been identified as a crime subject to universal jurisdiction under the InterAmerican Convention on Forced Disappearance of Persons. ${ }^{42}$ This regional

37. Id. art. $7(2)$.

38. Rodley, supra note 23, at 129-30.

39. Prosecutor v. Anton Furundzjia, ICTY, 10 Dec. 1998, II 156, 38 I.L.M. 346 (1999).

40. See Appendix.

41. F.A. Mann, The Definition of Jurisdiction, 111 ReCEUIL des Cours 95 (1964).

42. Inter-American Convention on the Forced Disappearance of Persons, signed 9 June 1994, OAS Doc. OEA/Ser.P/AG/doc.3114/94, art. 4 (1994), reprinted in 33 I.L.M. 1529 (1994) (not in force). 
initiative has been endorsed at the global level. The UN Declaration on the Protection of all Persons from Enforced Disappearances contains a provision on the exercise of universal jurisdiction with regard to persons presumed responsible for an act of enforced disappearance. ${ }^{43}$

\section{RELATIONSHIP WITH INTERNATIONAL CRIMINAL TRIBUNALS}

The ICTY and ICTR both enjoy primacy over domestic courts. This means that "(a)t any state of the procedure, the International Tribunal may formally request national courts to defer to the competence of the International Tribunal." 44 In practice, few courts seem to have refused to accept that they were under a duty to defer to the competence of the ICTY. Deferral has frequently occurred from courts outside the former Yugoslavia and Rwanda, i.e. from courts exercising universal jurisdiction.

The relationship between domestic courts and the ICC is a different one. Unlike domestic courts the ICC will not have universal jurisdiction itself. If a situation is not referred to it by the Security Council, the ICC will only be able to exercise jurisdiction if the crime occurred in a state which is a party to the Statute or if the crime was committed by a person who is a national of a party to the Statute. ${ }^{45}$ The ICC will therefore only be able to exercise jurisdiction on the basis of the territoriality principle and the active personality principle. ${ }^{46}$ This is likely to leave a large gap that can only be filled through the exercise of universal jurisdiction by domestic courts.

Accordingly, the ICC Statute emphasizes the importance of domestic prosecutions. Its preamble recalls "that it is the duty of every State to exercise its criminal jurisdiction over those responsible for international crimes." ${ }^{\prime 47}$ This may be read as an implicit reference to prosecutions carried out outside the territorial state. Both the preamble and Article 1 of the ICC Statute provide that the Court shall be complementary to national criminal jurisdictions. It will only be able to exercise jurisdiction after it has determined that the state which has jurisdiction over the crime is unwilling or unable genuinely to carry out the investigation or prosecution. ${ }^{48}$ The

\footnotetext{
43. United Nations Declaration on the Protection of all Persons from Enforced Disappearance, U.N. GAOR Res. 47/133, art. 14, 18 Dec. 1992.

44. ICTY Statute, art. 9 (2), 32 I.L.M. 1192 (1993); ICTR Statute, supra note 30 art.8 (2); see Bartram S. Brown, Primacy or Complementarity: Reconciling the Jurisdiction of National Courts and International Criminal Tribunals, 23 YALE J. INT'L L. 383 (1998).

45. ICC Statute, supra note 22, art. 12(2).

46. The term active personality principle refers to the basis of jurisdiction when the persons having the nationality of that forum are alleged to have committed the crime.

47. ICC Statute, supra note 22, pmbl.

48. Id., art. 17(1).
} 
"state which has jurisdiction" may therefore include states other than the state where the crime was committed, such as those exercising jurisdiction on the basis of the universality principle. The pressure that will be generated by the ICC when it is considering whether in a given situation a state has been unwilling or unable to carry out a genuine investigation or prosecution may be expected to spur the authorities of this state into action.

\section{OBSTACLES TO THE EXERCISE OF UNIVERSAL JURISDICTION}

A comparative analysis of the cases in which proceedings have so far been brought against persons suspected of having committed gross human rights offenses reveals several obstacles of a legal or practical nature that typically arise. Some of these difficulties may arise in any trial of crimes under international law. They include problems such as those relating to statutes of limitations, command responsibility, superior orders, and gender issues. A recent codification of the applicable rules of international law on these issues may be found in the Statute of the ICC. Some difficulties are, however, typical for the trial of crimes on the basis of universal jurisdiction and they will be considered here in some more detail. They include the lack of adequate implementing legislation, lack of specialized machinery, immunities, amnesties, evidentiary problems, and ineffective international supervision.

\section{A. Lack of Adequate Implementing Legislation}

In the Lotus case the Permanent Court of International Justice observed that the territoriality of criminal law is not an absolute principle of international law. The Court pointed out that every state remained free to adopt the principles for the exercise of criminal and civil jurisdiction which it regarded as most suitable, as long as it did not overstep the limits which international law placed upon its jurisdiction. ${ }^{49}$ In practice, however, states have tended to be more restrictive and this has certainly been the case with regard to the exercise of criminal jurisdiction on the basis of universality. States have been reluctant to provide for such jurisdiction in the absence of a specific permission in international law. Moreover, domestic courts have shown themselves unwilling to try defendants on the basis of universal jurisdiction in the absence of unambiguous provisions in domestic legislation

49. The case of the S.S. Lotus (France v. Turkey), Permanent Court of International Justice, 7 Sept. 1927, Ser. A, No. 10. 
allowing them to do so. This is not only because courts are reluctant to meddle in the internal affairs of another state but also because they do not want to come into conflict with the maxim nulla poena sine lege.

States are of course free to choose the manner in which they wish to give effect to their international obligations. This enables them to select the method of implementation that is most likely to be effective in their domestic context. ${ }^{50}$ In practice two approaches may be distinguished. Under the first approach, domestic legislation provides in general terms that crimes are subject to universal jurisdiction when the state in question is under an international obligation to do so. Penal law provisions then simply refer to the conventions in question. Examples of such provisions may be found in Danish, German, and Swiss laws. Under the second approach, domestic legislation itself defines in precise terms the offenses that are subject to universal jurisdiction. An example of this method is the Geneva Conventions Act adopted by a large number of states belonging to the Commonwealth.

Which of these two methods is to be preferred is debatable. The first has the advantage of greater flexibility. New developments in international law can be applied immediately without requiring a change in legislation. Its disadvantage, however, is that domestic judicial authorities may be reluctant to apply international legal concepts with which they are not familiar and which are not clearly defined in domestic law. Accordingly, domestic courts have shown themselves reluctant to apply offenses defined primarily in customary international law, such as crimes against humanity. ${ }^{51}$ The second approach does not have this drawback. It offers domestic authorities a legal framework with which they are familiar and on the basis of which they can act. The disadvantage of this method, however, is its rigidity.

In view of these differing legislative methods, it is not surprising that attempts to design model implementing legislation in the field of international humanitarian law have so far not been successful. Efforts to draft such legislation in fora such as the International Congress of Penal Law and the International Committee of the Red Cross have failed to achieve the necessary support from states. ${ }^{52}$ No attempt will therefore be made to suggest such model legislation here.

Only a few dozen states appear to have provided their courts with the specific competence to try certain gross human rights offenses under the

50. See Conclusions of the Chairman, in National Implementation of InTERnational Humanitarian Law 265 (Michael Bothe ed., 1990).

51. But see the order by the investigating magistrate in Brussels, supra note 24 .

52. The Geneva Conventions of 12 August 1949: Commentary II, at 264, n.2 (J.S. Pictet ed., 1952); similarly, Bothe, supra note 50. 
principle of universal jurisdiction..$^{53}$ Even in those states legislation tends to be quite a patchwork. Frequently, for example, laws implementing the Genocide Convention do not provide for the possibility to exercise jurisdiction on the basis of universal jurisdiction. This is because the Genocide Convention does not specifically require states parties to do so. Similarly, the absence of treaty provisions on the exercise of universal jurisdiction regarding crimes against humanity and crimes committed in non-international armed conflict explains why only few states have legal provisions allowing them to exercise universal jurisdiction with regard to these offenses. Domestic courts therefore frequently refuse to exercise universal jurisdiction in respect of these crimes on the grounds that domestic legislation does not provide them with a sufficient legal basis. Australian, French, and Swiss courts, amongst others, have taken this view. ${ }^{54}$

A curious phenomenon is that a number of states have limited their implementing legislation providing for the exercise of universal jurisdiction, ratione loci and ratione temporis, to offenses committed in certain places and during certain periods only. One example of such selectivity is the law enacted in the United Kingdom in 1991, rather misleadingly called the War Crimes Act, under which criminal proceedings may only be brought against UK citizens or residents who committed certain war crimes in Germany or German-occupied territory during the Second World War. ${ }^{55}$ The law is unlikely to cover more than a handful of cases. ${ }^{56}$ Another example is France, which has adopted legislation permitting its courts to exercise universal jurisdiction in respect of crimes against humanity and genocide, but only vis-à-vis crimes committed in the recent conflicts in the former Yugoslavia and Rwanda. ${ }^{57}$

Many states have also limited the competence of their courts to try defendants on the basis of universal jurisdiction ratione personae to persons that happen to be found within their jurisdiction. With regard to the offense of torture, states parties to the UN Convention against Torture may conceivably base such an interpretation on Article 7(2) of the Convention. However, such a restriction is incompatible with the grave breaches

53. According to one recent study, universal jurisdiction over all grave breaches defined in the Geneva Conventions (the most widely accepted ground for establishing universal jurisdiction) has so far been implemented by only 30 states. Richard van Elst, Implementing Universal Jurisdiction over Grave Breaches of the Geneva Conventions, 13 LEIDEN J. INT'L L. 815 (2000). The numbers may significantly increase, however, as states move to bring their legislation in conformity with the Statute of the ICC.

54. See Appendix.

55. War Crimes Act 1991, § 1 (Eng.). Australia has a similar law.

56. A.T. Richardson, War Crimes Act 1991, 55 Modern L. Rev. 73, 74 (1992).

57. See app. 
provisions of the Geneva Conventions that require states parties to search for perpetrators and bring them before their own courts wherever they are. ${ }^{58}$ German courts have been even more restrictive by requiring that a connection between Germany and the defendant (e.g. long-term residence in Germany or marriage to a German national) must be established before jurisdiction may be assumed..$^{59}$ The underlying idea that exercising jurisdiction without such connection would be interference in the internal affairs of the territorial state is clearly misconceived. For the exercise of universal jurisdiction in respect of gross human rights offenders no connection whatsoever between the prosecuting state and the suspect is required under either treaty law or customary international law. Belgium has shown the way in this respect by specifically empowering its competent authorities to bring proceedings against suspects that are not present on its territory.

In sum, very few states have adequate implementing legislation enabling the exercise of universal jurisdiction in respect of gross human rights offenses. Ratification of the ICC Statute ought to provide all states with a suitable occasion to review their legislation and ensure that their courts are able to exercise universal jurisdiction in respect of all offenses contained in the Statute.

\section{B. Lack of Specialized Institutions}

Investigating and prosecuting crimes on the basis of universal jurisdiction requires special skills, both in terms of knowing how to investigate crimes committed abroad and in terms of the specialized knowledge of international criminal law that is needed. It therefore makes sense to establish specialized units for this purpose, as an expression of the political will to combat gross human rights offenses wherever they occur. The staff of such units may not only be charged with investigating international crimes but also with liaising with the international criminal tribunals. It is true that sizeable war crimes units set up in Australia, Canada, and the United Kingdom have not been very successful at prosecuting Second World War cases. However, this lack of success should be blamed largely on the difficulties inherent in investigating crimes that occurred fifty or more years ago. It does not provide an argument against the usefulness of specialized institutions.

58. See generally supra note 26 .

59. See, e.g., Stefan van Heeck, Der aktuelle Fall: Die Anwendbarkeit deutschen Strafrechts auf Balkankriegsverbrechen, 13 Humanitäres VÖlKerReCHt 27, 32-33 (2000). 


\section{IMMUNITIES}

Because human rights offenses tend by definition to be committed by persons acting on behalf or with the consent or acquiescence of the state, a question which is likely to arise in proceedings on the basis of universal jurisdiction is whether a person accused of such offenses is exempt from criminal responsibility because he has acted in an official capacity. As a matter of fact, the point that official status does not constitute a defense in criminal proceedings in respect of crimes under international law has been specifically provided for in the Nuremberg Charter ${ }^{60}$ and the Statutes of the ICTY ${ }^{61}$ and the ICTR. ${ }^{62}$ In 1998, the Rome Conference on the Statute of the ICC adopted the following provision:

[O]fficial capacity as a Head of State or Government, a member of a Government or parliament, an elected representative or a government official shall in no case exempt a person from criminal responsibility under this Statute, nor shall it, in and of itself, constitute a ground for reduction of sentence. ${ }^{63}$

Strictly speaking, of course, this provision merely applies to proceedings before the ICC. However, the ICTY has observed, with regard to torture, that the rule is "indisputably declaratory of customary international law." 64 The rule therefore apparently also applies in proceedings before domestic courts. Although this finding was limited to the crime of torture, it may be assumed that the same principle applies to other crimes subject to universal jurisdiction. In fact, it would appear that the notion of immunity from criminal liability for crimes under international law perpetrated in an official capacity, whether by existing or former office holders, is fundamentally incompatible with the proposition that gross human rights offenses are subject to universal jurisdiction. ${ }^{65}$ Accordingly, a recent Belgian law explicitly provides that the immunity attributed to the official capacity of a person does not prevent criminal responsibility for genocide, crimes against humanity, and war crimes. ${ }^{66}$

Unfortunately, it cannot be said that recent domestic case law uniformly supports this approach. In Ex parte Pinochet the British House of Lords

60. Nuremberg Charter, art. 7, 88 U.N.T.S. 280.

61. ICTY Statute, supra note 44, art. 7.

62. ICTR Statute, supra note 30, art. 6.

63. ICC Statute, supra note 22, art. 27(1).

64. Furundzija Judgment, supra note 39, II 140.

65. See Andrea Bianchi, Immunity Versus Human Rights: The Pinochet Case, 10 European J. INT'L L. 237, 276-77 (1999).

66. Loi relative à la répression des infractions graves de droit international humanitaire, art. 5(3), 10 Feb. 1999, Moniteur Belge, 23 Mar. 1999. English trans. in 38 I.L.M. 918 (1999). 
determined in an important judgment that under UK law a former head of state does not enjoy immunity in respect of the crime of torture. ${ }^{67}$ Nevertheless, it left no doubt that serving heads of state do enjoy such immunity. ${ }^{68}$ The French Cour de cassation (Constitutional Court) similarly ruled on 13 March 2001 without much discussion that Colonel Qaddafi could not be prosecuted in France for his alleged share in the blowing up of a French aircraft in 1989, for the simple reason that as Libya's head of state he enjoyed immunity from prosecution. ${ }^{69}$

\section{AMNESTIES}

An issue on which there is no case law yet but which is likely to arise sooner or later is whether domestic courts in third states are bound by amnesties awarded in the territorial state.

It has been argued that awarding amnesties to perpetrators of gross human rights offenses is in itself prohibited under international law. ${ }^{70}$ If this proposition is correct, such amnesties are null and void and they cannot prevent proceedings in another state. International practice offers considerable, but not yet entirely conclusive, support for this line of argument. The Human Rights Committee has in one of its general comments taken the view that amnesties in respect of acts of torture are "generally incompatible with the duty of States to investigate such acts." declared that perpetrators of enforced disappearances shall not benefit from amnesties. $^{72}$ The Inter-American Commission on Human Rights has ruled that amnesty laws that prevent the prosecution of crimes such as political

67. UK House of Lords: Regina v. Bartle and the Commissioner of Police for the Metropolis and Others Ex Parte Pinochet, 24 Mar. 1999, 38 I.L.M. 581 (1999). Christine M. Chinkin, Casenote 93 AM. J. INT'L L. 703 (1999).

68. Under the UK's State Immunity Act, a serving head of state enjoys absolute immunity from prosecution. The Committee against Torture has requested the UK to amend this act to bring it into line with the Convention against Torture. U.N. Doc. CAT/C/SR.36 II 11 (27 Nov. 1998).

69. Abandon des poursuites contre le colonel Kadhafi, Le Monde, 13 Mar. 2001.

70. Naomi Roht-Arriaza, State Responsibility to Investigate and Prosecute Grave Human Rights Violations in International Law, 78 Cal. L. Rev. 451, 485 (1990); Kai Ambos, Impunity and International Criminal Law: A Case Study on Colombia, Peru, Bolivia, Chile and Argentina, 18 Hum. RTs. L. J. 1, 7 (1997). Louis Joinet, in his capacity as Special Rapporteur on amnesty laws of the UN Sub-Commission on Prevention of Discrimination and Protection of Minorities, has been more ambivalent. See U.N. Doc. E/CN.4/Sub.2/1985/16 II 51 \& 62 (21 June 1985).

71. General Comment on art. 7; General Comment No. 20, U.N. GAOR, Hum. Rts. Comm., 44th Sess., U.N. Doc. CCPR/C/21/Rev.1/Add.3.

72. U.N. Declaration on the Protection of all Persons from Enforced Disappearance, supra note 43 , art. 18. 
killings, torture and forced disappearances, are incompatible with the right to judicial recourse. ${ }^{73}$ In the terms of Article 17 of the ICC Statute such amnesties could be an indication of "unwillingness or inability of the State genuinely to prosecute"; they would therefore not prevent the ICC from declaring a case admissible. ${ }^{74}$ In July 1999, the UN Secretary-General announced that he would sign the Sierra Leone Peace Agreement (which provides in Article 9 for a sweeping "absolute and free pardon and reprieve to all combatants and collaborators in respect of anything done by them in pursuit of their objectives"), but subject to the important proviso that the "amnesty and pardon shall not apply to international crimes of genocide, crimes against humanity, war crimes and other serious violations of international humanitarian law. ${ }^{175}$

On the other hand, not all international practice on this matter points in the same direction. The United Nations itself has been far from consistent in its attitude to amnesties for perpetrators of gross human rights offenses. ${ }^{76}$ Perhaps more significantly, South Africa's Constitutional Court has held in $A Z A P O$ v. South Africa that the country's truth and reconciliation process, including its amnesty procedure, is not incompatible with international law and this ruling has found some support in the literature. ${ }^{77}$ Reliance is sometimes also placed on Article 6(5) of Protocol II to the Geneva Conventions which provides:

At the end of the hostilities, the authorities in power shall endeavour to grant the broadest possible amnesty to persons who have participated in the armed

73. See, e.g., Annual Report of the Inter-American Commission on Human Rights 1992-1993 Nos. 28/92 \& 29/92, 2 Oct. 1992, at 41 \& 154; see also Robert Kogod Goldman, Amnesty Laws and International Law: A Specific Case, in Impunity of Gross Human Rights Violations 209 (Int'l Comm'n Jurists eds., 1992). However, the Inter-American Commission and Court have been reluctant to declare illegal all amnesties for perpetrators of human rights abuses. See Ellen Lutz, Responses to Amnesties by the Inter-American System for the Protection of Human Rights, in The Inter-American System of Human Rights 345, 368 (David Harris \& Stephen Livingstone eds., 1998).

74. On the ambiguity of the ICC Statute with regard to amnesties, see Michael P. Scharf, The Amnesty Exception to the Jurisdiction of the International Criminal Court, 32 CORNELL INT'L L. J. 507 (1999).

75. UN Daily Press Briefing, 5-7 July 1999.

76. Michael Scharf, Swapping Amnesty for Peace: Was There a Duty to Prosecute International Crimes in Haiti?, 31 Tex. INT'L L. J. 1 (1996).

77. Dugard has criticized the judgment for paying insufficient attention to international law considerations. But he accepts that "state practice is too unsettled to support a rule obliging states to prosecute those alleged to have committed crimes against humanity under all circumstances and that the present state of international law does not bar the granting of amnesty in circumstances of the kind prevailing in South Africa." John Dugard, Is the Truth and Reconciliation Process Compatible with International Law? An Unanswered Question, 13 S. Afr. J. Hum. Rts. 258, 267 (1997); see also John Dugard, Dealing with Crimes of the Past: Is Amnesty Still an Option?, 12 LeIDEN J. INT'L L. 100115 (1999). 
conflict, or those deprived of their liberty for reasons related to the armed conflict, whether they are interned or detained. ${ }^{78}$

As the International Committee of the Red Cross has pointed out, this provision merely states that combatants should not be punished for legitimate acts of hostility. It does not provide a legal basis for awarding amnesties to persons who have violated international law. ${ }^{79}$

But even if it is assumed that at least some types of amnesties are not incompatible with international law, the bottom line is that in any case amnesties lack extra-territorial effect. They therefore do not affect treaty obligations or entitlements under customary international law to bring gross human rights offenders to justice wherever they are. ${ }^{80}$ This applies most clearly to blanket amnesties that are obviously self-serving, such as the one Augusto Pinochet awarded himself and his colleagues before stepping down from office. The same reasoning applies, however, to more palatable types of amnesties, such as the ones awarded by South Africa's Truth and Reconciliation Commission. In practice, this should cause no major difficulties. A bona fide amnesty could be taken into account by a prosecutor when exercising his or her discretion whether or not to bring a prosecution (assuming there is no duty to prosecute under the Geneva Conventions or the UN Convention against Torture). Similarly, when imposing a sentence a court could legitimately take into account as a mitigating factor the fact that the defendant had benefited from a respectable amnesty measure in the territorial state.

Finally, it would not be contrary to Article 14(7) of the International Covenant on Civil and Political Rights to bring a defendant who has benefited from an amnesty in the territorial state to justice in another state on the basis of universal jurisdiction. Procedures for awarding amnesties do not amount to "acquittal" within the meaning of Article 14(7). The prohibition against ne bis in idem contained in that provision therefore does not apply. Even if it were assumed that the procedures of some truth and reconciliation commissions are sufficiently judicial in character to meet this standard, the Human Rights Committee has held that Article 14(7) does not prohibit trial for the same offense in another state. ${ }^{81}$

78. Protocol (II) Additional to the Geneva Conventions of 12 Aug. 1949, and Relating to the Protection of Victims of Non-International Armed Conflicts (Protocol II), 8 June 1977, art. 6, II 5, 1125 U.N.T.S. 609 (entered into force 7 Dec. 1978), reprinted in 16 I.L.M. 1442 (1977).

79. Letter from the ICRC, quoted in Naomi Roht-Arriaza \& Lauren Gibson, The Developing Jurisprudence on Amnesty, 20 Hum. RTs.Q. 843, 865 (1998).

80. With regard to torture, see the Furundzija judgment, supra note 39, II 155-56.

81. A.P. v. Italy, Comm. No. 204/1986, 2 Nov. 1987, U.N. Doc. A/43/40, at 242; see generally International Covenant on Civil and Political Rights, adopted 16 Dec. 1966, 


\section{E. EVIDENTIARY PROBLEMS}

One of the greatest difficulties in bringing proceedings on the basis of universal jurisdiction may be of a practical nature. How does one obtain the necessary evidence to enable a defendant's conviction for offenses committed abroad? The authorities of the territorial state can be expected to be reluctant to render assistance, even when they are obliged to do so, for the simple reason that they may bear co-responsibility for the offenses. In some cases, they may strongly object and actively try to frustrate investigations. Even with the backing of the Security Council, the ICTY and the ICTR have found it difficult to obtain the necessary co-operation from the authorities of the territorial states. Another problem is that witnesses often have to be traced in distant states. Even when they can be found they may be reluctant to testify for fear of reprisals against themselves or their families. Furthermore, numerous documents will need to be translated. Investigations on the basis of universal jurisdiction therefore tend to be considerably more expensive and time-consuming than investigations based on the territoriality principle.

In recognition of these problems, the UN Declaration on the Principles of International Co-operation in the Detection, Arrest, Extradition and Punishment of Persons Guilty of War Crimes and Crimes against Humanity specifically provides that states shall co-operate with each other in the collection of information and evidence which would help to bring to trial persons indicted for war crimes and crimes against humanity. ${ }^{82}$ Some of the treaties providing for the exercise of universal jurisdiction similarly oblige the parties to render each other mutual legal assistance in the investigation and prosecution of these crimes. ${ }^{83}$ These provisions obviously supplement any existing bilateral and multilateral treaty obligations to render mutual legal assistance in criminal matters that may be in force between the states in question. A useful checklist of the types of assistance that may be required may be found in the Statute of the ICC. They include assistance with the identification and locating the whereabouts of persons or the location of items, the taking of evidence, the serving of documents, the examination of places or sites, the execution of searches and seizures, the

G.A. Res. 2200 (XXI), U.N. GAOR, 21 st Sess., Supp. No. 16, art. 14 U.N. Doc. A/6316 (1966), 993 U.N.T.S. 171 (entered into force 23 Mar. 1976).

82. Declaration on the Principles of International Co-operation in the Detection, Arrest, Extradition and Punishment of Persons Guilty of War Crimes and Crimes against Humanity. G.A. Res. 3074 (XXVIII), adopted 3 Dec. 1973, reprinted in 13 I.L.M. 230 (1974).

83. Protocol (I) Additional to the Geneva Conventions of 12 August 1949, and Relating to the Protection of Victims of International Armed Conflicts (Protocol I), 8 June 1977, art. 88, 1125 U.N.T.S. 3 (entered into force 7 Dec. 1978), reprinted in 16 I.L.M. 1391 (1977); UN Convention against Torture, supra note 17, art. 9. 
provision of records and documents, and the protection of victims and witnesses. ${ }^{84}$

The extent to which states have complied with requests for foreign assistance in the investigation and prosecution of human rights offenses subject to universal jurisdiction is not known. Anecdotal evidence, however, suggest that the situation is far from satisfactory. Mutual legal assistance in general is difficult enough. Delicate negotiations are often required to match the requirements of one jurisdiction with the practices of another. ${ }^{85}$ Most convictions on the basis of universal jurisdiction appear to have been based essentially on eyewitness testimony that happened to be available in the prosecuting state without any significant assistance from the authorities of the territorial state. Any foreign legal assistance tended not to be obtained through official channels but only through personal contacts of the investigators.

Apart from relying on mutual legal assistance, there are several measures that states may take unilaterally to facilitate the investigation and prosecution of gross human rights offenses committed abroad. In particular, methods of gathering evidence abroad and of reducing reliance on direct oral testimony may be usefully considered. A few examples indicate the range of possibilities. A Belgian investigating magistrate has conducted extensive rogatory missions to Rwanda, Togo, and Ghana when investigating crimes committed in Rwanda. ${ }^{86} \mathrm{~A}$ Swiss court has traveled to Rwanda to visit the site of the crime and to collect statements from witnesses unwilling or unable to come to Switzerland. ${ }^{87}$ The ICTY has explored the use of written depositions for use at trial and the taking of evidence by video-link. ${ }^{88}$

Some of these suggestions may sound like heresy to lawyers raised within the adversarial tradition. It should however provide them with food for thought that practically no prosecutions on the basis of universal jurisdiction have so far been successfully conducted in common law countries. An important reason for this appears to be the more restrictive rules of evidence, in particular those preventing reliance on written depositions. Accordingly, a report produced in 1996 under the auspices of the British Home Office recognizes that the exercise of universal jurisdiction in Britain can only be expected to function effectively if reforms of the rules

\footnotetext{
84. ICC Statute, supra note 22, art. 93(1); see also ICTY Statute, supra note 44, art. 29; ICTR Statute, supra note 30 art. 28.

85. UK Home Office, Steering Committee Report, Review of Extra-Territorial Jurisdiction 25 (July 1996).

86. See app.

87. See app.

88. See Rules of Procedure and Evidence ICTY, Rules 71 \& 90, available at <http:// www.un.org/icty/basic.html>.
} 
governing the admissibility of evidence are adopted along the lines proposed above. ${ }^{89}$

\section{F. Ineffective International Supervision}

One contributing factor (although not an "obstacle" in the sense of the preceding paragraphs) to the frequent failure of states to implement their international obligations with respect to universal jurisdiction both in law and in practice is the lack of systematic international supervision.

Of the international treaties that provide for the exercise of universal jurisdiction in respect of gross human rights offenses only the UN Convention against Torture has its own supervisory body. ${ }^{90}$ Unfortunately, the Committee against Torture has long failed to pay more than perfunctory attention to compliance with the universal jurisdiction provisions of the Convention when reviewing implementation reports by states parties. While it has given regular attention to the need to adopt enabling legislation for this purpose, the Committee has for many years shown little interest in the actual application of such legislation in individual cases. ${ }^{91}$ Only after General Pinochet had been arrested in the United Kingdom in 1998, the Committee adopted a forceful recommendation with respect to the actual exercise of universal jurisdiction in a specific case:

The Committee finally recommends that in the case of Senator Pinochet of Chile, the matter be referred to the office of the public prosecutor, with a view to examining the feasibility of and if appropriate initiating criminal proceedings in England, in the event that the decision is made not to extradite him. This would satisfy the State party's obligations under articles 4 to 7 of the Convention and article 27 of the Vienna Convention on the Law of Treaties $1969 .{ }^{92}$

89. UK Home Office Report, supra note 85.

90. Although the Geneva Conventions lack a supervisory body, the International Committee of the Red Cross, through its Advisory Service on International Humanitarian Law, has done useful work in assisting states parties to adopt appropriate implementing legislation with regard to universal jurisdiction.

91. In only two individual cases the Committee has asked states parties why they had not initiated an investigation in accordance with the Convention's universal jurisdiction provisions. See questions posed to the Netherlands, with regard to the visit by General Pinochet there in 1994 (the matter was first raised by the Netherlands itself, U.N. Doc. CAT/C/SR.210 II II 8 \& 43) and to Colombia, with regard to the residence of General Avril (U.N. Doc. CAT/C/SR.239 II 45). See Chris Ingelse, De rol van het Comité in de ontwikkeling Van het VN-Verdrag tegen Foltering 292-95 (1999), English trans. to be published as The UN Committee against Torture: An Assessment (2001).

92. U.N. Doc. CAT/C/SR.360, at 5 (19 Nov. 1998). 
It would be useful if the Committee were to undertake a more combative role on universal jurisdiction. For example, it might adopt a "general comment" providing that universal jurisdiction should not only be established in law but that also be exercised in practice and that states parties should extend each other mutual legal co-operation when investigating relevant cases. ${ }^{93}$

As was pointed out above, a considerable impetus towards implementation of the principle of universal jurisdiction was provided by Security Council decisions supporting the establishment and the operation of the ICTY and ICTR. Through these decisions states were urged to arrest and detain persons suspected of having committed crimes within the jurisdiction of the Yugoslavia and Rwanda Tribunals and to either hand them over to the relevant Tribunal or to bring them to justice themselves. For example, in Resolution 978 (1995) the Security Council:

Urge[d] States to arrest and detain, in accordance with their national law and relevant standards of international law, pending prosecution by the International Tribunal for Rwanda or by the appropriate national authorities, persons found within their territory against whom there is sufficient evidence that they were responsible for acts within the jurisdiction of the International Tribunal for Rwanda (emphasis added). ${ }^{94}$

In other cases, however, the Security Council has not specifically called for the exercise of universal jurisdiction in respect of gross human rights offenders. In Resolution 1264 (1999) on East Timor, for example, the Council merely demanded in general terms that those responsible for acts of violence in East Timor be brought to justice. It would therefore be useful if the Council would more frequently urge states to exercise universal jurisdiction in respect of gross human rights offenses being committed in particular states, perhaps as an intermediary step before referring a situation to the ICC. It would also be useful if the Council, in the absence of relevant treaty monitoring procedures, were to undertake a monitoring role. In a recent report to the Security Council the Secretary-General made the felicitous suggestion that the Council undertake such a role both with regard to the adoption of domestic legislation and the initiation of prosecutions. He recommended that the Council:

Urge Member States to adopt national legislation for the prosecution of individuals responsible for genocide, crimes against humanity and war crimes. Member States should initiate prosecution of persons under their authority or on their territory for grave breaches of international humanitarian law on the basis

93. INGELSE, supra note 91, at 301.

94. S.C. Res. 978 (1995), U.N. SCOR, 3504th mtg., II 1 , U.N. Doc. S/RES/978 (1995). 
of the principle of universal jurisdiction and report thereon to the Security Council. ${ }^{95}$

\section{SAFEGUARDS AGAINST THE ABUSE OF UNIVERSAL JURISDICTION}

From the point of view of the defendant, the exercise of universal jurisdiction presents some special difficulties that deserve to be taken quite seriously.

To begin with, the decision to initiate proceedings on the basis of universal jurisdiction may be objected to. States exercising jurisdiction on this basis may be accused of jurisdictional imperialism because universal jurisdiction is only likely to be exercised in powerful states with regard to crimes committed in less powerful states. At first sight, the cases summarized in the Appendix would appear to support this accusation. The large majority of universal jurisdiction cases have been conducted in OECD states with respect to crimes committed outside these states. ${ }^{96}$ On the other hand, international obligations to prosecute gross human rights offenses on the basis of universal jurisdiction are relatively straightforward and are contained in treaties that have been widely ratified. It can hardly be held against states that they are prepared to comply with their international obligations, especially if they have initiated proceedings against their own nationals in connection with similar offenses.

There are, nevertheless, inherent risks to the fairness of proceedings far removed from the site of the crime and against a defendant who may not understand the language and the culture in which he is being brought to justice. It should therefore be stressed that like any defendant in criminal proceedings, the defendant being tried on the basis of universal jurisdiction is fully entitled to fair treatment in accordance with applicable international human rights standards. All semblance of unfairness should be avoided. To underscore the point, treaties providing for universal jurisdiction tend to contain specific safeguards guaranteeing the right to a fair trial of persons being brought to justice on this basis. ${ }^{97}$ Particular attention ought to be paid to the defendant's right to interpretation and translation, his right to effective legal representation, and his right to consular assistance under the Vienna

95. Report of the Secretary-General to the Security Council on the Protection of Civilians in Armed Conflict, U.N. Doc. S/1999/957, 8 Sept. 1999.

96. But see Appendix, the proceedings initiated in Senegal against former President Habré of Chad.

97. Geneva Conv. I, art. 49, Geneva Conv. II, art. 50, Geneva Conv. III, art. 129, Geneva Conv. IV, art. 146, supra note 26; Convention against Torture, supra note 17, art. 8. 
Convention on Consular Relations. Prosecuting authorities and courts should be sensitive to cultural differences and to gender issues, for example the reluctance of women from some cultures to testify about sexual violence to which they have been subjected because this might result in their rejection. Defendants should be tried by civilian courts. The policy of some states to let military courts try civilians accused of gross human rights offenses raises questions about the fairness of such proceedings and ought to be reconsidered. Finally, defendants must not be sentenced to death. ${ }^{98}$

\section{CONCLUDING OBSERVATIONS}

The exercise of universal jurisdiction in respect of gross human rights offenses is an impressive indicator of the continuing globalization of the administration of criminal justice. This is because in genuine universal jurisdiction cases-i.e. cases that cannot simultaneously be based on the passive personality principle or the protective principle-judicial authorities are not acting on behalf of their own domestic legal system but on behalf of the international legal order. While this is to be expected from international institutions specifically established for this purpose-such as the international criminal tribunals-it presents a striking phenomenon when done by domestic institutions.

The exercise of universal jurisdiction in respect of gross human rights offenses raises numerous legal and practical difficulties that cannot be easily overcome. However, experience so far shows that, contrary to conventional wisdom, it can be made to work. True, the House of Lords appeared scarcely up to the task of handling the intricate questions of international law raised by the Pinochet case. However, courts in other West European states have demonstrated remarkable ability and confidence in applying ambivalent legal concepts that have confounded scholars and diplomats for decades, such as the crime of genocide and the distinction between international and non-international armed conflict. The resulting case law is likely to have a stimulating effect on the development of international law in this field.

States that profess to be serious about the exercise of universal jurisdiction in respect of gross human rights offenses should begin by ensuring that their domestic legislation specifically enables their courts to exercise jurisdiction in respect of all crimes identified in the Statute of the ICC, without any restrictions ratione loci, ratione temporis or ratione

98. Cf. ICC Statute, supra note 22, art. 77; ICTY Statute, supra note 44, art. 24; ICTR Statute, supra note 30, art. 23. 
personae. A suitable occasion for this is when they are reviewing their laws to bring them into line with the Statute of the International Criminal Court. Next, they should consider whether their laws of evidence do not in fact prevent successful proceedings on the basis of universal jurisdiction, e.g., by restricting reliance on written depositions. Furthermore, in view of the specialist knowledge of international (criminal) law and of international legal co-operation that is required, serious consideration should be given to the establishment of specialist investigation and prosecution units that could also be charged with liaising with international criminal tribunals and courts.

The most frequently asked question about universal jurisdiction in respect of gross human rights offenses is whether its exercise is obligatory or merely permissive. The short answer is that states parties to the Geneva Conventions and the UN Convention against Torture have undertaken an obligation to exercise universal jurisdiction in respect of grave breaches and torture, respectively. Under customary international law states are moreover entitled to exercise universal jurisdiction in respect of genocide, crimes against humanity, war crimes and torture.

The exercise of universal jurisdiction in respect of gross human rights offenses is not for the faint-hearted. Territorial states are unlikely to react kindly to it. This is of course because the introduction of such proceedings implies a clear failure on their part to comply with their international obligations. It should therefore cause no surprise that Chile protested vehemently against the detention of Augusto Pinochet in the United Kingdom, that Mauritania responded by cutting all military cooperation and introducing visa restrictions in response to the arrest of one of its military officers in France, and that Congo introduced proceedings against Belgium before the International Court of Justice in response to the international arrest warrant issued against its Foreign Minister. In view of such strong reactions, prosecutors are unlikely to bring universal jurisdiction proceedings lightly. The possibility of abuse is one of the key arguments of the opponents of universal jurisdiction. In fact, the cases surveyed for this paper reveal no evidence whatsoever of frivolous or politically motivated prosecutions.

\section{APPENDIX: UNIVERSAL JURISDICTION CASES}

\section{Australia}

The 1945 War Crimes Act, as amended in 1988, is so restrictive that it can hardly qualify as an example of a law enabling the exercise of universal jurisdiction. Its scope is limited to war crimes committed in Europe during the Second World War by Australian citizens or residents. The three 
prosecutions initiated under the amended law all failed to result in convictions. The War Crimes Special Investigations Unit with fifty staff was dissolved in 1992 and it is considered unlikely that any further prosecutions will be carried out under this law. ${ }^{99}$

With respect to crimes against humanity and genocide the position is even worse. On 1 September 1999, in Nulyarimma v. Thompson the Federal Court of Australia concluded that, in the absence of enabling legislation, no person may be tried for genocide before an Australian court. ${ }^{100}$

\section{Austria}

On 31 May 1995, Dusko Cvjetkovic, a Bosnian Serb seeking asylum in Austria, was acquitted by a district court in Salzburg of having committed genocide against Muslims in Bosnia. The case was apparently poorly prepared by the prosecution as none of its five witnesses managed to identify the defendant during the trial. Significantly, however, the Austrian Supreme Court had earlier agreed that Austrian courts had jurisdiction to try the case. ${ }^{101}$

\section{Belgium}

Belgium probably has the most far-reaching and up-to-date legislation permitting the exercise of universal jurisdiction. Its 1993 law applies to war crimes committed both in international and non-international armed conflicts. ${ }^{102}$ Jurisdiction may be exercised even when the suspect is not present on Belgian territory. ${ }^{103}$ Moreover, the law has recently been amended to expand the range of crimes to which it applies. This 1999 amendment

99. See Gillian Triggs, Australia's War Crimes Trials: All Pity Choked, in THE LAW OF WAR Crimes: National and International Approaches 123-49 (Timothy L.H. McCormack \& Gerry J. Simpson eds., 1997).

100. Nulyarimma and others v. Thompson, Federal Court of Australia, Full Court, 1 Sept. 1999, 39 I.L.M. 20 (2000).

101. See Axel Marschik, The Politics of Prosecution: European National Approaches to War Crimes, in The Law of War Crimes, supra note 99, at 79-81. The decision appears not to have been published.

102. Loi relative à la répression des infractions graves aux Conventions internationales de Genève du 12 août 1949 et aux Protocoles I et II du 8 juin 1977, additionnels à ces Conventions, 16 June 1993, Moniteur Belge, 5 Aug. 1993.

103. A. Andries, E. David, \& C. van den Wijngaert, Commentaire de la loi du 16 juin 1993 relative à la répression des infractions graves aux droit international humanitaire, REVUE de dROIt péNAl et de CRININOLOGIE 1114, 1173 (1994). 
enables the courts to additionally exercise universal jurisdiction in respect of perpetrators of genocide and crimes against humanity, as defined in the Statute of the ICC. ${ }^{104}$ No form of official immunity may be invoked to prevent the application of this law.

A juge d'instruction (investigating magistrate) based in Brussels has carried out extensive investigations of crimes committed during the civil war in Rwanda. Some of these individuals were suspected of having been involved in the killing of Belgian blue helmets in Rwanda and some were Belgians suspected of involvement in the Rwanda genocide. However, there were also some genuine universal jurisdiction cases in which there was no such link with Belgium. ${ }^{105}$ As part of his investigations, the juge d'instruction carried out four rogatory missions, three to Rwanda, and one to Togo and Ghana. ${ }^{106}$

On 8 June 2001, Alphonse Higaniro, Vincent Ntezimana and two Catholic nuns, Consolata Mukangango and Julienne Mukabutera were convicted by a Brussels court of various counts of murder for their share in the Rwandan genocide and subsequently sentenced to long prison sentences. ${ }^{107}$

\section{Canada}

In spite of the fact that Canada has allocated significant resources to the prosecution of war crimes, no one has been convicted so far of gross human rights offenses committed abroad. ${ }^{108}$ One reason for this is that in 1994 in the Imre Finta case the Supreme Court of Canada laid down such high standards of proof for the conviction of perpetrators of war crimes and crimes against humanity that prosecutions became an unrealistic option. ${ }^{109}$

104. Loi relative à la répression des violations graves de droit international humanitaire, 10 Feb. 1999, Moniteur Belge, 23 Mar. 1999, (English translation in) 38 I.L.M. 918 (1999). Damien Vandermeersch, a juge d'instruction based in Brussels had determined several months earlier, in proceedings against general Pinochet, that crimes against humanity could be investigated in Belgium, in accordance with the principle of universal jurisdiction, on the basis of customary international law. Juge d'instruction à Bruxelles, 6 Nov. 1998, Revue de Droit Pénal et de Criminologie 278-300 (1999); Luc Reydams, Casenote 93 Am. J.INT'L L. 700 (1999).

105. Luc Reydams, Universal Jurisdiction over Atrocities in Rwanda: Theory and Practice, 4 Eur. J. Crim. L. Crim. Justice 18, 37 (1996).

106. Damien Vandermeersch, La répression en droit belge des crimes de droit international, 68 Int'L Rev. Pen. L. 1093, 1121-22 (1997).

107. A Bruxelles, les "quatre du Rwanda" sont tous déclarés coupables, Le Monde, 8 June 2001.

108. See Canada's War Crimes Program: Annual Report 2000-2001 (2001).

109. Regina v. Finta, Supreme Court of Canada, 24 Mar. 1994; Irwin Cotler, Casenote, 90 AM. J. INT'L L. 460 (1996). 
The Government's declared policy then became to remove suspected perpetrators of gross human rights offenses from Canada rather than to bring them to justice. This not-in-my-backyard policy is obviously incompatible with Canada's obligations under the Geneva Conventions and the Convention against Torture. The 2000 Crimes Against Humanity and War Crimes Act, which provides for the exercise of universal jurisdiction in respect of persons present in Canada who are suspected of genocide, crimes against humanity and war crimes, may contribute to a more active prosecutions policy.

\section{Denmark}

On 25 November 1994, Refik Saric, a Bosnian Serb seeking asylum in Denmark, was sentenced to eight years imprisonment for having murdered and tortured inmates of a concentration camp in Bosnia. ${ }^{110}$ The conviction was confirmed on appeal. ${ }^{111}$ The Danish courts based their jurisdiction on the grave breaches provisions in Articles 129 and 130 of the Third Geneva Convention and Articles 146 and 147 of the Fourth Geneva Convention in conjunction with Article 8(5) of the Danish Penal Code which provides them with jurisdiction to try perpetrators of certain crimes when Denmark is bound by a treaty to do so. ${ }^{112}$ The investigation of the case was greatly facilitated by the fact that the defendant was recognized in the Danish refugee center in which he stayed by thirty-nine persons who testified that they had witnessed how the defendant ill-treated inmates of the concentration camp. The investigation was impeded, however, by the fact that in spite of repeated requests the prosecution received no legal assistance from the authorities in Bosnia and Croatia. ${ }^{113}$

110. Prosecution v. Refik Saric, Third Chamber of the Eastern Division of the Danish High Court, 25 Nov. 1994. See Rafaelle Maison, Les premiers cas d'application des dispositions pénales des Conventions de Genève par les jurisdictions internes, 6 Eur. J. INT'L L. 260 (1995).

111. Prosecution v. Refik Saric, Supreme Court of Denmark, 15 Aug. 1995, 1995 UgeSKRIFt for Retsvaesen at 838.

112. See Marianne Holdgaard Bukh, Prosecution Before Danish Courts of Foreigners Suspected of Serious Violations of Human Rights or Humanitarian Law, 6 Eur. Rev. Pub. L. 339, 341 (1994).

113. Erik Merlung, National Implementation: The Universal Jurisdiction: The Saric Case, in The Punishment of War Crimes: International Legal Perspective, (Report of a conference organized by the Belgian Red Cross and the Belgian Ministry of Foreign Affairs) 12, 13 (9 Oct. 1996). 


\section{France}

On 6 January 1998, the French Cour de cassation (Supreme Court) agreed that Wenceslas Munyeshyaka, a Rwandan priest residing in France accused of having committed genocide and crimes against humanity against Tutsi refugees in Rwanda, could be brought to justice in France on the basis of universal jurisdiction. ${ }^{114}$ The court acknowledged that jurisdiction to try such crimes derived inter alia from a law by which France had given effect to Security Council Resolution 955. ${ }^{115}$ No judgment on the merits has been adopted so far.

On 3 July 1999, Ely Ould Dha, a lieutenant in the Mauritanian army taking a military training course in France, was arrested on suspicion of having tortured detainees in a prison in Mauritania in 1990 and $1991 .{ }^{116}$ Mauritania reacted strongly by ending all military cooperation with France and introducing visa requirements for French nationals. On 28 September 1999, the suspect was released pending the investigation and subsequently he was found to have returned to Mauritania. ${ }^{117}$ Legal proceedings against him are, however, continuing in his absence.

\section{Germany}

Of all states, Germany has so far been the most active in exercising universal jurisdiction in respect of gross human rights offenses. This may partly be explained by the presence in its territory of large numbers of asylum seekers from the former Yugoslavia. Under Article 6(9) of the German Penal Code, German criminal law applies to acts that, because of an international treaty binding on Germany, must be prosecuted even in cases when such acts have been committed abroad. Under Article 6(1) of the same Code, German criminal law applies to the crime of genocide when committed abroad. ${ }^{118}$ Disappointing, however, has been the German courts'

114. In re Wenceslas Munyeshyaka, Cour de Cassation, Paris, 6 Jan. 1998, 102 Revue Genérale de droit International Public 825 (1998); Brigitte Stern, Casenote 93 Am. J. Int'L L. 525 (1999); see also Brigitte Stern, La compétence universelle en France: le cas des crimes commis en ex-Yougoslavie et au Rwanda, 40 German Y. B. INT'L L. 280 (1997).

115. Law 96-432 of 22 May 1996.

116. Fédération internationale des Ligues des droits de I'homme, Press Release, 5 July 1999.

117. Mauritania: Torture-charge Mauritanian Home from France, Reuters, 5 Apr. 2000.

118. See Herwig Roggeman, Strafvervolgung von Balkankriegsverbrechen aufgrund des Weltrechtsprinzips_ein Ausweg?," 47 Neue Juristische Wochenschrift 1436 (1994); Dietrich Oehler, Verfolgung von Völkermord im Ausland, 10 Neue Zeitschrift für Strafrecht 485 (1994); Dorothée Füth, Die Verfolgung von Völkermord durch deutsche Gerichte aufgrund des Weltrechtspflegeprinzips, 10 HuMANITÄRES VÖLKERRECHT 38 (1997). 
insistence that there must some linkage between the defendant and Germany_-such as long term residency or employment in Germany-as a condition for the exercise of universal jurisdiction by the German courts (but see below).

On 23 May 1997, Novislav Djajic was found guilty of having been an accessory to fourteen cases of murder and sentenced to five years imprisonment by a court in Munich. He was acquitted of having been an accessory to genocide. ${ }^{119}$

On 26 September 1997, Nikola Jorgic, a former leader of a Serb paramilitary group, was found guilty by a court in Düsseldorf on eleven counts of genocide and sentenced to life imprisonment. The evidence against him consisted of a television interview in which he confirmed his leadership role and a long series of eyewitness testimonies. ${ }^{120}$ On 30 April 1999, the Bundesgerichtshof upheld the conviction and confirmed that German courts had jurisdiction on the basis of the Genocide Convention and because there were sufficient links with Germany, inter alia because the defendant had been residing in Germany for a long time. ${ }^{121}$ On 12 December 2000, the Bundesverfassungsgericht (Constitutional Court) rejected the defendant's final appeal against this judgment.

On 29 November 1999, Maksim Sokolovic was sentenced to nine years imprisonment by the same Düsseldorf court for having inflicted severe illtreatment on Muslims in Serbia. On appeal, on 21 February 2001, the Bundesgerichtshof appeared to accept for the first time that no linkage with Germany was required for the exercise of universal jurisdiction.

On 15 December 1999, a fourth Bosnian Serb, Djuradi Kusljic, was convicted of genocide and sentenced to life imprisonment by the same Munich court that had convicted Novislav Djajic.

\section{Mexico}

On 12 January 2001, a Mexican court decided to permit the extradition to Spain of Ricardo Miguel Cavallo, a former military officer accused of having committed atrocities under the military dictatorship in Argentina. ${ }^{122} \mathrm{His}$

119. Prosecution v. Novislav Djajic, Bayerisches Oberstes Landesgericht, 23 May 1997, 19 Neue Juristische Wochenschrift 392 (1998); J.M. Safferling, Casenote, 92 Am.J. Int'L L. 528 (1998).

120. Prosecution v. Nikola Jorgic, Oberlandesgericht Düsseldorf, 26 Sept. 1997.

121. Prosecution v. Nikola Jorgic, Bundesgerichtshof, 30 Apr. 1999, NeUe Zeitschrift für Strafrecht 1999 at 396, (casenote by Kai Ambos).

122. Human Rights Watch, Mexico's Decision to Extradite Accused Argentine Torturer Hailed, News Release, 3 Feb. 2001. 
extradition had been requested by a Spanish investigating magistrate. The ruling is still under appeal.

\section{Netherlands}

On 11 November 1997, the Hoge Raad (Supreme Court) of the Netherlands ruled that Darko Knesevic, a Bosnian Serb residing in the Netherlands accused of various war crimes committed against Muslims in BosniaHerzegovina, could be tried by a Dutch military court on the basis of universal jurisdiction. The court found that jurisdiction of the Dutch courts was not limited to offenses committed during wars in which the Netherlands had been a party. ${ }^{123}$ This finally clarified an ambiguity in the Dutch War Crimes Act of 1952 that was inspired by the view taken by B.V.A. Röling, the Dutch judge on the Tokyo Tribunal. Röling had maintained that the Geneva Conventions recognize the principle of universal jurisdiction only between belligerent states. ${ }^{124}$ The defendant has not been tried on the merits so far.

On 20 November 2000, the Amsterdam District Court ordered the prosecution of Desi Bouterse, the former army commander of Suriname, for his involvement in political killings committed in Suriname in 1982. The ruling was remarkable for the fact that in 1982 Dutch legislation did not yet provide for the exercise of universal jurisdiction in respect of crimes against humanity and torture. ${ }^{125}$

\section{Senegal}

On 3 February 2000, the Dakar Regional Court indicted former Chadian President Hissein Habré on torture charges and placed him under house arrest. This appears to have been the first time that proceedings were brought in an African state against an alleged human rights offender on the basis of universal jurisdiction. However, on 4 July 2000, after apparent intervention by the Senegalese President, another court dismissed the

123. Prosecution v. Darko Knesevic, Supreme Court of the Netherlands, 11 Nov. 1997, Nederlandse jurisprudentie 1998, 463. English trans. in 1 Y.B. INT'L Hum. L. 601 (1998).

124. See B.V.A. Röling, The Law and the National Jurisdiction, ReCuell Des Cours 1960-II, 359; see also the illuminating conversation between Cassese and Röling in B.V.A. RöLING \& Antonio Cassese, The Tokyo Trial and Beyond 95-98 (1993).

125. In re: Bouterse, Amsterdam District Court, 20 Nov. 2000, available at <http:// www.rechtspraak.nl.html>. 
charges on the grounds of lack of jurisdiction. ${ }^{126}$ On 20 March 2001, Senegal's Cour de Cassation (Constitutional Court), confirmed that, in the absence of domestic legislation providing for universal jurisdiction in respect of torture, Habré could not be tried in Senegal. ${ }^{127}$

\section{Spain}

On 4 and 5 November 1998, the Audiencia Nacional (National Court) agreed that Spanish courts had jurisdiction to try alleged perpetrators of genocide committed in Argentina and Chile. The court based its ruling on the principle of universal jurisdiction although in fact it relied primarily on the passive personality principle because many of the victims were Spanish nationals. ${ }^{128}$ The rulings cleared the way for the international arrest warrant for General Pinochet issued by Judge Garzón.

\section{Switzerland}

On 18 April 1997, Goran Grabez, a Bosnian Serb seeking asylum in Switzerland, was acquitted by a military tribunal in Lausanne of having committed various serious crimes in concentration camps in BosniaHerzegovina. The tribunal considered that it had not been proven beyond a reasonable doubt that the defendant had been in the camps at the times alleged. Damages were awarded to the defendant. The tribunal agreed, however, that it would have had jurisdiction to try the case under Article 109 of the Swiss Military Code. ${ }^{129}$

On 30 April 1999, Fulgence Niyonteze, a Rwandan citizen seeking asylum in Switzerland, was sentenced to life imprisonment by the same military tribunal in Lausanne for murder, attempted murder, incitement to murder and war crimes committed in Rwanda in 1994. This was the first conviction in Europe of a Rwandan national in connection with the Rwandan genocide. The tribunal refused to consider charges of genocide and crimes against humanity on the grounds that these crimes are not

126. Human Rights Watch, News Release, 4 July 2000.

127. Guengueng \& Others v. Habré, Cour de cassation, 20 Mar. 2001, available at <http:// www.hrw.org/french/themes/habre-cour_de_cass.html>.

128. Spanish National Court, Criminal Division, Case 19/97, 4 Nov. 1998 \& Case 1/98, 5 Nov. 1998. María del Carmen Márquez Carrasco \& Joaquín Alcaide Fernández, Casenote, 93 АM. J. INT'L L. 690, 691 (1999).

129. Prosecution v. Goran Grabez, Tribunal militaire de division 1, Lausanne, 18 Apr. 1997; Andreas R. Ziegler, Casenote, 92 AM. J. INT'L L. 78 (1998). 
recognized as being subject to universal jurisdiction under Swiss law. ${ }^{130}$ Witnesses were flown from Rwanda to Lausanne to testify during the trial. Before the beginning of the trial the court also visited Rwanda to collect statements from witnesses unwilling or unable to come to Switzerland. On appeal, the sentence was reduced to fourteen years. ${ }^{131}$

\section{United Kingdom}

In September 1997, Mohammed Ahmed Mahgoub, a Sudanese medical doctor residing in Scotland, was arrested and charged under Section 134 of the 1988 Criminal Justice Act with having committed torture in a secret detention center in Sudan. ${ }^{132}$ Section 134 implements the UN Convention against Torture. In May 1999, the charges against the suspect were dropped, apparently for lack of evidence. ${ }^{133}$

On 1 April 1999, seventy-eight-year-old Anthony Sawoniuk was sentenced to life imprisonment at the Old Bailey in London for having murdered in 1942 two Jews in what is now Belarus. This was the first and so far only conviction under the War Crimes Act of 1991. Pursuant to this law, criminal proceedings may be brought against UK citizens or residents in the UK who committed certain war crimes in Germany or German-occupied territory during the Second World War. In spite of its grand title, the law therefore has a very limited scope, both ratione loci and ratione temporis. A special unit of the Metropolitan Police has been created to investigate relevant cases.

\section{United States}

In the United States, the principle of universal jurisdiction in respect of gross human rights offenses committed abroad, has been relied upon with considerable success in civil lawsuits, pursuant to the Alien Tort Claims Act and the Torture Victim Protection Act. ${ }^{134}$ However, a legal basis for

130. En la cause Fulgence Niyonteze, Tribunal militaire de division 2, Lausanne, 30 Apr. 1999.

131. En la cause Fulgence Niyonteze, Tribunal militaire d'appel 1a, Geneva, 26 May 2000; Tribunal militaire de cassation, Yverdon-les-Bains, 27 Apr. 2001.

132. Ken Symon, "Torture Centre" Doctor Charged, Sunday Times (London), 21 Sept. 1997, at 12.

133. Scottish Crown Office Drops Torture Prosecution against Sudanese Doctor, RedRess, Press Release, 27 May 1999 <at http://www.redress.org.html>.

134. For an overview, see Beth Stephens, Expanding Remedies for Human Rights Abuses: Civil Litigation in Domestic Courts, 40 German Y. B. Int'L L. 117 (1997). 
exercising universal jurisdiction in criminal cases exists only for the offense of torture and no prosecutions have been initiated under this provision so far. ${ }^{135}$ The 1996 War Crimes Act grants jurisdiction over grave breaches of the Geneva Conventions but merely on the basis of the active and passive personality principle and not on the basis of universal jurisdiction.

135. US Report to the UN Committee against Torture, 15 Oct. 1999, U.N. Doc. CAT/C/28/ Add.5, II 189 (9 Feb. 2000). 